\title{
Effectiveness of Multimodal Glossing Reading Program on English Vocabulary Acquisition
}

\author{
Nunpaporn Durongbhandhu ${ }^{1} \&$ Danuchawat Suwanasilp ${ }^{1}$ \\ ${ }^{1}$ Faculty of Humanities and Social Sciences, Rajamangala University of Technology Tawan-ok, Thailand \\ Correspondence: Danuchawat Suwanasilp, Department of English for International Communication, Faculty of \\ Humanities and Social Sciences, Rajamangala University of Technology Tawan-ok, Chonburi, Thailand.
}

Received: April 20, 2021

Accepted: May 17, 2021

Online Published: May 18, 2021

doi: 10.5539/elt.v14n6p62

URL: https://doi.org/10.5539/elt.v14n6p62

\begin{abstract}
Vocabulary is an essential factor in English language learning. The competency in vocabulary acquisition enables learners to develop their language skills, especially, reading skill. Presently, with the advent of technology, teaching media with visual aid is used worldwide for media-assisted language learning. The study aimed to develop, implement Multimodal Glossing Reading Program (MMGR), used for enhancing English vocabulary acquisition, and compare the program with Textual Glossing Reading Program (TGR) and a control group. One control group and two experimental groups were performed by 72 university learners of English as a Foreign Language (EFL). An experimental research with randomized pretest-posttest control group was used. Pre-and post-tests of meaning and form recognition were administered. The scores learners obtained from the pre-test and post-test within groups and between groups were analyzed by MANOVA. The findings revealed that MMGR was effective than TGR and the control group. It is suggested that teaching English vocabulary through MMGR program not only helps learners have the ability in vocabulary acquisition, but also enables the instructors to use the program as a potentially supplemental material or alternative method in teaching vocabulary as well.
\end{abstract}

Keywords: glossing, incidental vocabulary learning, multimedia learning, vocabulary acquisition

\section{Introduction}

One of the most important factors of successful reading comprehension is the quality of vocabulary known for the reader because vocabulary plays a pivotal role in reading comprehension. 98 percent of words is required to be known for FL/L2 (foreign language/ second language) learners to understand the reading texts (Schmitt, Jiang, \& Grabe, 2011). It is impossible that full comprehension of texts can be accomplished without understanding its vocabulary (Nation, 2001), and it is believed that all researchers can agree to is that learning vocabulary is an essential part of mastering in second language learning (Schimtt, 2008). Many ESL teachers take it into prior consideration and try to find the best way to teach vocabulary, and it is impossible to teach all the words of language to learners. Consequently, many strategies were selected to have learners master in vocabulary recognition. However, many learners still forget what they have learnt very soon or they cannot use those vocabulary in real situations at all. The problem makes learners have awareness of their limitations in their vocabulary knowledge block their ability to communicate and comprehend the reading text effectively (Read, 2004).

From many problems in vocabulary teaching to be raised, a method that can build learners' vocabulary is an extensive reading (Boutorwick, Macalister, \& Elgort, 2019). A large number of FL/L2 reading studies focus on the potential benefit of extensive reading in promoting the language learners' vocabulary learning. Extensive reading is useful for learners to build their vocabulary growth. In other words, the extensive reading called incidental learning helps build up and accumulate the leaners' vocabulary incidentally (Nation, 2001). Furthermore, it is the means to develop good reading habit, and encourage learners to develop a love of reading (Richards \& Schmidt, 2002). More specifically, extensive reading enables learners to meet learned words repeatedly to increase sight vocabulary (Coady, 1997), and lead to considerable vocabulary growth. As mentioned previously, many ESL teachers have an interest in extensive reading, and are increasing aware of the important role of extensive reading in developing FL/L2 learners' vocabulary language knowledge. 
As we have known about the importance of incidental vocabulary acquisition through extensive reading, meaningful vocabulary teaching technique which helps FL/L2 students improve their reading comprehension and vocabulary acquisition is called glossing (Majuddin, 2014). Teaching vocabulary by glosses can be focused because they have the potential to draw FL/L2 learners' attention to incidental lexical items during reading (Laufer \& Girsai, 2008). Glossing, the way to foster FL/L2 vocabulary learning, was commonly used to enable language learners to process unknown words and facilitate vocabulary learning (Duan, 2018; Sun, 2017).

With the advent of technology, computer technology supports educational activities in a meaningful way. Most students use multimedia to enhance their learning (Vazquez-Calvo, Zhang, Pascual, \& Cassany, 2019). The use of computer assisted language learning (CALL) in L2 vocabulary are spread out (Laufer, 2009). Computer brings new ways that words can be glossed from text to multimedia glosses. Computerized glossing is widely used by FL teachers, and it is deserved as an effective way to teach vocabulary incidentally through reading in a FL/L2 environment (Gettys, Imhof, \& Kautz, 2001). Glosses can be placed on the screen to have learners practiced which differ from a traditional, paper-based text.

As mentioned above, it was conducive to the design of reading program application based on the combination in glossing and incidental learning used among multimodal learning environment. Therefore, the main purpose of the present study was to develop the reading application programs. In addition to program development, the research was designed to examine the effect of multimedia program implementation in teaching on learners' competency in vocabulary recognition. The conceptual model of the study is displayed in Figure 1.

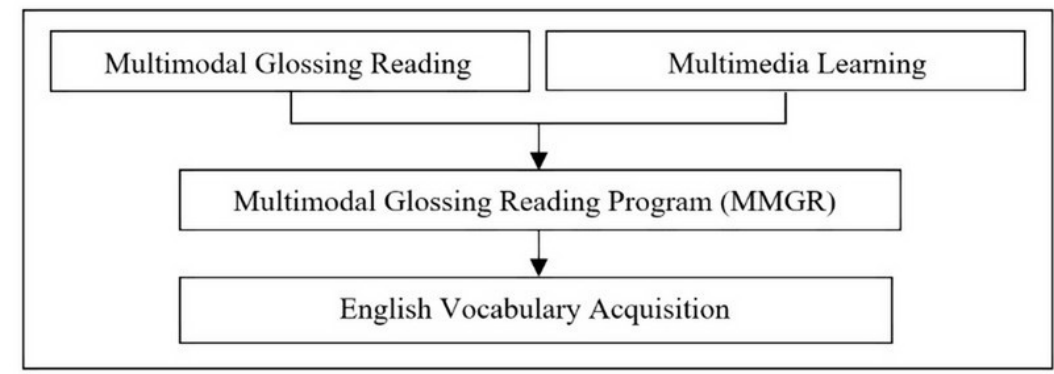

Figure 1. The conceptual model of study

As a result, the current study aims to answer the following research questions:

1) Does MMGR program enhance students' vocabulary recognition?

2) Are there any significant differences among the groups of MMGR, TGR, no treatment used on the vocabulary post-test in form and meaning recognition?

\section{Literature Review}

\subsection{Incidental Vocabulary Learning via Reading}

Kanoksilpatham and Khamkhien (2012) have said that most researchers propose two techniques of teaching vocabulary in two ways (Nation, 2005; Stahl, 1999). The first technique is learning vocabulary from context or "incidental learning, another technique is called "implicit instruction". In contrast, "direct intentional learning" is a decontextualized way of vocabulary learning, and it occurs when the learners' attention is specifically focused by teachers or learners themselves on learning new words (Nation, 2001). Vocabulary can be taught in the word list explicitly with the analysis of affix or dictionary used. Incidental vocabulary learning refers to vocabulary acquisition when learners' attention is on reading comprehension rather than on the goal of learning vocabulary (Hulstijn, 2003, p. 349). Lexical researchers confirm that most vocabulary in both L1 and L2 is acquired incidentally through repeated exposure during reading (Anderson \& Freebody, 1983; Hulstijn, 2001; Jenkins, Stein, \& Wysocki, 1984; Nagy, Anderson, \& Herman, 1987). Paribakht and Wesche (1997) stated that vocabulary enhancement activities via reading make learners memorize words, define word meaning, and use the words in proper context based on process in L2 vocabulary acquisition: selective attention, recognition, manipulation, interpretation, and production. While intentional vocabulary learning "decontextualized learning" (word list) may help students memorize vocabulary for test, learners have a tendency to rapidly forget words memorized from lists (Oxford \& Scarcella, 1994).

Incidental vocabulary learning through various areas can be found in many research studies, such as vocabulary learning via reading (Pellicer-Sánchez, 2014; Rott, 1999; Webb, 2005), listening (Vidal, 2003), speaking (Ellis, 
1995), writing (Webb, 2005), and integrated skills (Joe, 1998; Paribakht \& Wesche, 1999). In Early studies, incidental vocabulary acquisition through reading activity was focused. Later, researchers found that listening activity was another good way to enhance incidental vocabulary acquisition (Tang, 2020). However, among various areas, incidental vocabulary learning through reading is emphasized more rigorously than any other area because of many proven empirical studies. Vidal (2011) compared the effect of listening and reading on incidental vocabulary acquisition. The results showed that participants from reading task performed better. Meanwhile, many other studies have been conducted to investigate the differences between listening input and reading input, most of which confirmed that reading-only task could better promote incidental vocabulary acquisition than listening-only task (Chang \& Miao, 2018).

\subsection{Multimedia Learning}

Computer-based multimedia learning environments which is composed of pictures and words offer a potentially marvelous forum for improving learners' understanding (Mayer \& Moreno, 2002). When multimedia learning is raised, it is inevitable to explain about the cognitive theory of multimedia learning (CTML). CTML, raised by Mayer (2014) offers to give an explanation of how verbal and visual information was activated. The theory which draws on dual coding theory, cognitive load theory, and constructivist learning theory is based on three major assumptions. First, dual channels assumption points out that there are 2 separate channels to process visual and verbal information (Paivio, 1986). In other words, the auditory/verbal channel processes information in the form of spoken words, narration, or sounds via the ears; and the visual/pictorial channel processes information in the form of pictures, graphs, videos, etc. received through the eyes. Second, limited capacity assumption portrays the limitation of each channel capacity (Baddeley, 1999; Sweller, Ayres, \& Kalyuga, 2001). When an illustration is presented, the learner is able to hold a few images in the visual channel of working memory at any one time. During the narration, a few words can be caught in the working memory at any one time. Lastly, active processing assumption illustrates that words and images are selected, organized, and integrated with the prior knowledge drawn from their long-term memory brought back into their short-term memory to facilitate processing (Mayer, 2014; Wittrock, 1989).

\subsection{Glosses and Multimedia Glosses}

Glossing, which is usually presented at the end of a written text or near the unknown word, is a method of providing definition/explanation, or translation of unknown words while students are reading for comprehension (Nation, 1990, p. 44). Glosses can be used for FL and L1/L2 learning, such as L1 glossing (translation in native language), L2 glossing (definition, synonym or antonym), single-marginal glossing, L1 multiple-choice glossing, L2 dictionary definition, use of sentence contexts etc.

With the advances in computer technology, multimedia glosses are used in place of traditional paper-and-pen annotations. Unlike the paper-based text, multimedia glosses have substantial benefits. First, besides textual information, multimedia glosses can be placed with multimodal information such as images, video clips, sound, etc. by adding them in different locations on the screen (Abuseileek, 2011). It can be further adopted in CALL reading environment by a combination of various glossing modes, such as textual with video animations (Akbulut, 2007), textual plus music and sound (Kaplan-Rakowski \& Loranc-Paszylk, 2019). Glosses can be categorized into different types. For example, L1 versus L2 glosses (Jacobs, Dufon, \& Hong, 1994; Ko, 2012), traditional paper-based glosses versus computerized glosses (i.e., textual/visual/audio glosses) (Bowles, 2004; Severin, 2019), topic-level and word-level glosses (Sakar \& Ercetin, 2005). In this paper, the type of L1 (definition in Thai), and visual (picture) representation is adopted.

\subsection{Empirical Studies on Using Multimedia Glosses on L2 Vocabulary Learning}

Many researchers have investigated the effects of various multimedia environments on L2/FL vocabulary learning. Yeh and Wang (2003) tried to show the effect of multimedia vocabulary annotation and learning style on vocabulary learning. The results indicated that the most effect type of vocabulary annotation was text plus picture. Yoshii (2006) examined the effect of various glossing incidental vocabulary learning in a multimedia context. Results showed that the textual-pictorial glosses group outperformed the textual glosses group on the definition-supply test.

Another study was done by Kim and Gilman (2008) on the effects of multimedia components such as visual text, spoken-text, and graphics on L2 vocabulary learning. The resulted showed that participants who received visual text, and add graphic mode, or who received visual text, added spoken text, and added graphic mode outperformed the other groups. Jones (2004) explored the effects of pictorial and written annotations on L2 vocabulary learning. The results showed that the written annotation and the pictorial and written annotations groups has significantly higher scores than the comparison group, but the difference between the pictorial 
annotation group and the comparison group was not meaningful. Yanguas (2009) studied the effects of textual glosses, picture glosses, a combination of textual, picture, and an unglossed condition with 94 students taking fourth semester Spanish at a college in the United States. No significant difference was found between groups on the productive knowledge post-test. However, students in the glossed conditions score significantly higher on the immediate and three-week recognition post-tests.

In another experiment, Zarei and Rashvand (2011) examined the effect of multimedia on L2 vocabulary learning in different captioning conditions. They investigated the effect of verbatim and nonverbatim interlingual and intralingual subtitle on L2 vocabulary comprehension and production. The results indicated that nonverbatim subtitles has positive effect on vocabulary comprehension regardless of they were interlingual or intralingual or not. Rassaei (2018) compared audio and textual computer gloss conditions with unglossed condition in a study with 93 participants from intermediate, adult EFL class in Iran. The audio and textual glosses contained the same L1 definitions. The results of production and recognition post-tests showed that participants in the glossing conditions scored significantly higher than their counterparts in the unglossed condition.

\section{Method}

\subsection{Research Design}

To achieve the purpose of research, the study employed experimental research design with a randomized pretest-posttest control group design (McMillan \& Schumacher, 2010, p. 274) to be able to examine the accuracy of the conceptual model of the study. The design of study is succinctly portrayed in Figure 2.

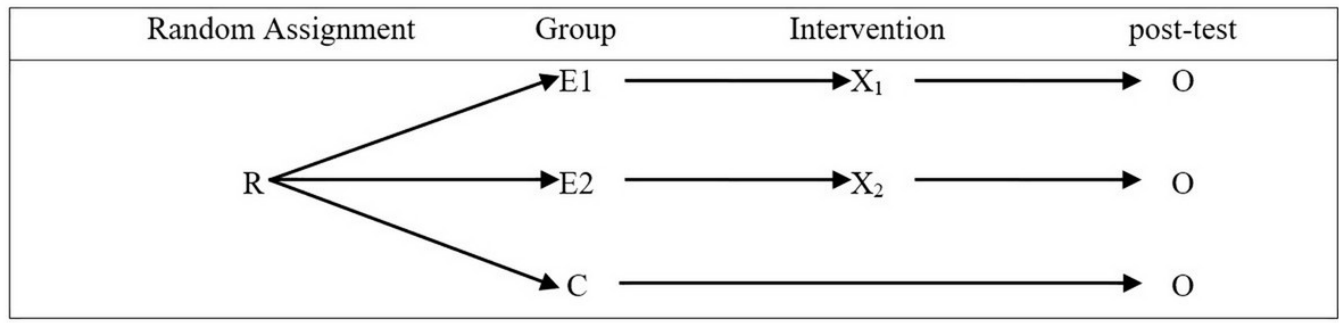

Figure 2. Design of study
Note: $\mathrm{E} 1=$ experimental group 1
$\mathrm{E} 2=$ experimental group 2
$\mathrm{C}=$ control group
$\mathrm{X}_{1}=$ MMGR treatment
$\mathrm{X}_{2}=\mathrm{TGR}$ treatment
$\mathrm{O}=$ post-test

\subsection{Participants}

The participants were intermediate university learners of English as a Foreign Language at Rajamangala University of Technology Tawan-ok, one group randomly assigned to each task. The overall number of learners taking part in the study was 72 , Group $1(\mathrm{~N}=24)$ read the passages with multimodal glossing for Target Words (MMGR program), Group $2(\mathrm{~N}=24)$ read the passages with textual glossing for Target Words (TGR program), and Group $3(\mathrm{~N}=24)$, the one with no glossing for Target Words (the control group).

Summary of participants' characteristics are presented in Table 1 below;

Table 1. Demography of the participants

\begin{tabular}{|c|c|c|c|c|c|c|c|c|}
\hline \multirow{2}{*}{$\begin{array}{l}\text { Demographic } \\
\text { aspects }\end{array}$} & \multicolumn{2}{|c|}{$\begin{array}{l}\text { MMGR group } \\
(n=24)\end{array}$} & \multicolumn{2}{|c|}{$\begin{array}{l}\text { TGR group } \\
(n=24)\end{array}$} & \multicolumn{2}{|c|}{$\begin{array}{l}\text { Control group } \\
(n=24)\end{array}$} & \multicolumn{2}{|c|}{$\begin{array}{l}\text { Total } \\
(n=72)\end{array}$} \\
\hline & $\mathrm{N}$ & $\%$ & $\mathrm{~N}$ & $\%$ & $\mathrm{~N}$ & $\%$ & $\mathrm{~N}$ & $\%$ \\
\hline \multicolumn{9}{|l|}{ Gender } \\
\hline Male & 5 & 20.83 & 6 & 25.00 & 5 & 20.83 & 16 & 22.22 \\
\hline Female & 19 & 79.17 & 18 & 75.00 & 19 & 79.17 & 56 & 77.78 \\
\hline \multicolumn{9}{|l|}{ Age } \\
\hline 18 & 5 & 20.83 & 6 & 25.00 & 5 & 20.83 & 16 & 22.22 \\
\hline 19 & 10 & 41.66 & 8 & 33.33 & 9 & 37.51 & 27 & 37.50 \\
\hline 20 & 9 & 37.51 & 10 & 41.67 & 10 & 41.67 & 29 & 40.27 \\
\hline Total & 100 & 100.00 & 100 & 100.00 & 100 & 100.00 & 100 & 100.00 \\
\hline
\end{tabular}




\subsection{Data Collection Tools and Procedure}

The primary instruments employed in the study comprise MMGR, TGR program and vocabulary test. The detailed account of the research instruments is demonstrated as follows:

\subsubsection{Design}

Both MMGR and TGR program were established by using ADDIE model which was composed of analysis, design, development, implementation, and evaluation (McGriff, 2000).

Firstly, need analysis form with IOC index at 0.95 for content validity testing was distributed and made by learners to investigate readers' need, reading problem, program characteristic, topic preference, and learning style for preparing the activities in the program.

Next, reading passages were selected for 10 activities in the program by using the difficulty of readability check according to Fry's readability graph (Fry, 1997). Reading passages which were used in this study were adopted by the concept of glossing used with text in reading passage (Hulstijn, Hollander, \& Greidanus, 1996). The unknown English vocabularies which were selected from 10 reading passages were selected by 50 learners from the other groups to be the Target Words in the programs. After that, the researchers selected the picture and Thai meaning associated with unknown English vocabulary to create the multimodal grossing/textual grossing in the program.

Next, the programs were designed by determining instruction, activity display, 50-minute time duration practice per each unit, practice's procedure detail in the web application created by PHP HTML CSS and PHP Myadmin, and program manuals were made. Many parts, Welcome Page, Learning Objective, Main Menu, Contents/Theme Exercises, Reading Comprehension Activity, and Vocabulary Recognition Activity, were displayed on the program screen (see Appendix for program screen). Before actual implementation, the programs are assessed the content validity index which was not less than 0.80) (Di Iorio, 2005, p. 218), and had trial experiment with pilot study. Then, programs were implemented in two experimental groups. MMGR was used in one experimental group and the other group used TGR.

Finally, both programs were evaluated to check the effectiveness of program used. Both MMGR and TGR program designs were adopted by ADDIE model which had similarity in all processes; however, the differences between MMGR and TGR were the multimodal glossing displaying for Target Words in MMGR program were pictorial-Thai meaning textual presentation, but the glossing displaying for Target Words in TGR program were Thai meaning text-only.

\subsubsection{Materials}

Each activity included the reading passage about 800-1,000 words with multimodal glossing/textual glossing for Target words (about 15-17 words in each activity) on the screen. It was a relatively easy passage which the learners could be able to read without more difficulty. A pilot test was administered prior to the experiment. The follow-up interview found that the reading passage was appropriate for the learners.

In the study, the three groups read the same reading passages with same reading instructions, but under different glossing types. MMGR program was the multimodal glossing displaying for Target Words with pictorial-Thai meaning textual presentation. Whenever the participants clicked on the Target Words, the pictorial-Thai meaning textual appeared on the screen. TGR program was the glossing displaying for Target Words with only Thai meaning text-only. Whenever the participants clicked on the Target Words, Thai meaning text-only appeared on the screen. After the participants read the passage in the program, they were asked to do the activities which were activity for reading comprehension and activity for vocabulary recognition in the programs.

\subsubsection{Vocabulary Test}

The test of vocabulary comprised of two sections. Sixty-five multiple choices test was a test of vocabulary in form recognition test, and seventy-five multiple choices test was a test of vocabulary in meaning recognition test. The content validity of the test was checked by 3 experts in the field of English language teaching and assessment. The tests met high degree of content validity.

\subsubsection{Procedure}

Before starting the study, 72 participants were chosen to check their vocabulary knowledge with vocabulary pre-test. In the intervention period, MMGR program was used in a group of students practicing reading with MMGR, TGR program was used in a group of students practicing with TGR program, and none of the program was used in a control group. The programs were implemented during second semester on December, 2020 as specified in detail followed by the program instruction. After program treatment had been done, the post-test was 
used in both control group and two experimental groups without prior notification to see how much effect program had on vocabulary learning.
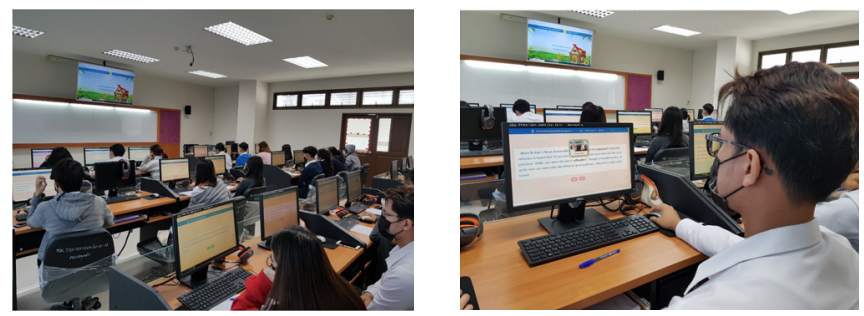

Figure 3. The participant used MMGR program

\subsection{Data Analysis}

The data obtained in this study were analyzed through descriptive and inferential statistical in the SPSS program. Statistical techniques used in the analysis of the research questions were MANOVA and mean, percentage, standard deviation. MANOVA was used to investigate the ability of learners' vocabulary recognition enhancement comparing among two experimental and control groups, and paired t-test, standard deviation was used to compare the pre-test and post-test in each group.

\section{Results}

The findings were given as follows;

\subsection{Differences between the Pre-Test and Post-Test's Score of Each Group Based on Program Treatment}

\subsubsection{The Group with MMGR Program Treatment}

Table 2 presents the comparison of variable dependents in a group treated by MMGR program.

Table 2. The comparison of score between the pre-test and the post-test in MMGR program

\begin{tabular}{|c|c|c|c|c|c|c|c|}
\hline \multirow{2}{*}{ Dependent Variable } & \multirow{2}{*}{$n$} & \multicolumn{2}{|c|}{ pre-test } & \multicolumn{2}{|c|}{ post-test } & \multirow{2}{*}{$t$} & \multirow{2}{*}{$p$} \\
\hline & & $M$ & $S D$ & $M$ & $S D$ & & \\
\hline $\begin{array}{l}\text { Score of vocabulary test in } \\
\text { form recognition test }\end{array}$ & 24 & 22.54 & 9.15 & 42.29 & 11.15 & $-13.19 *$ & .00 \\
\hline $\begin{array}{l}\text { Score of vocabulary test in } \\
\text { meaning recognition test }\end{array}$ & 24 & 22.42 & 11.15 & 48.17 & 8.37 & $-11.70^{*}$ & .00 \\
\hline
\end{tabular}

$* p<.01$

The mean score of the pre-test in form recognition test was 22.54 and the post-test was 42.24 . Similarly, the mean score of the pre-test in meaning recognition test was 22.42 and post-test was 48.17 . The post-tests of form and meaning recognition test were outstandingly higher than the pre-test with statistical significance level at 0.01 . (See Table 2)

\subsubsection{The Group Treated by TGR Program}

Table 3 presents the comparison of variable dependents in a group treated by TGR program.

Table 3. The comparison of score between the pre-test and the post-test in TGR program

\begin{tabular}{|c|c|c|c|c|c|c|c|}
\hline \multirow{2}{*}{ Dependent Variable } & \multirow{2}{*}{$n$} & \multicolumn{2}{|c|}{ pre-test } & \multicolumn{2}{|c|}{ post-test } & \multirow{2}{*}{$t$} & \multirow{2}{*}{$p$} \\
\hline & & $M$ & $S D$ & $M$ & $S D$ & & \\
\hline $\begin{array}{l}\text { Score of vocabulary test in } \\
\text { form recognition test }\end{array}$ & 24 & 22.00 & 7.94 & 35.67 & 5.70 & $-12.04 *$ & .00 \\
\hline $\begin{array}{l}\text { Score of vocabulary test in } \\
\text { meaning recognition test }\end{array}$ & 24 & 22.13 & 7.89 & 40.88 & 4.61 & $-15.79 *$ & .00 \\
\hline
\end{tabular}

The comparison between the pre-test and the post-test was provided in Table 3. The mean score of form and recognition test and meaning recognition test in the pre-test were 22.00 and 22.13. The score of a post-test kept rising up to 35.67 and 40.88 respectively. As a result, A post-test score was higher than a pre-test with statistical significance at the level 0.01. (See Table 3) 


\subsubsection{A Control Group with No Treatment}

Table 4 presents the comparison of variable dependents in a control group.

Table 4. The comparison of score between the pre-test and the post-test in the control group

\begin{tabular}{|c|c|c|c|c|c|c|c|}
\hline \multirow{2}{*}{ Dependent Variable } & \multirow{2}{*}{$n$} & \multicolumn{2}{|c|}{ pre-test } & \multicolumn{2}{|c|}{ post-test } & \multirow{2}{*}{$t$} & \multirow{2}{*}{$p$} \\
\hline & & $M$ & $S D$ & $M$ & $S D$ & & \\
\hline $\begin{array}{l}\text { Score of vocabulary test in } \\
\text { form recognition test }\end{array}$ & 24 & 22.00 & 7.94 & 35.67 & 5.70 & $-12.04 *$ & .00 \\
\hline $\begin{array}{l}\text { Score of vocabulary test in } \\
\text { meaning recognition test }\end{array}$ & 24 & 22.13 & 7.89 & 40.88 & 4.61 & $-15.79 *$ & .00 \\
\hline
\end{tabular}

Table 4 showed that there was no difference of the score between the pre-test and the post-test in the control group. In that, the pre-test score was 22.13, and the post-test was 24.99. Both dependent variables have the quite similarity in before and after treatment. (See Table 4)

4.1.4 The results of MANOVA analysis of dependent variables among the groups threated by MMGR, TGR, and the control group

Table 5 presents the result of MANOVA analysis with two statistic tests.

Table 5. MANOVA analysis with two statistic tests

\begin{tabular}{llllllll}
\hline Statistic Test & \multirow{2}{*}{ Value } & $F$ & $\begin{array}{l}\text { Hypothesis } \\
d f\end{array}$ & $\begin{array}{l}\text { Error } \\
d f\end{array}$ & $p$ & $\eta^{2}$ & Observed Power $^{\mathrm{d}}$ \\
\hline Pillai's Criterion & .78 & 22.18 & 4 & 138 & .00 & .39 & 1.00 \\
Wilks' Lambda & .23 & 37.64 & 4 & 136 & .00 & .53 & 1.00 \\
\hline
\end{tabular}

${ }^{\mathrm{d}}$ Computed using alpha $=.05$

$* p<.01$

A one-way multivariate analysis of variance (MANOVA) was conducted to discover whether dependent variables had been affected by program treatment or not. As can be seen in Table 5, a statistically significant MANOVA effect was obtained, Pillai's trace $=0.78, \mathrm{~F}=22.18$ with $p$ value of .00 which is less than the significance level. It means three sample groups (two experimental groups treated by different programs) had the vocabulary test score in form and meaning recognition test with statistically significant difference at the 0.01 level.

In analysis of Wilks' Lambda, Wilks $=.23$, degree of freedom $=4, p$ value $=.00$ with the effect size of dependent variables in two experimental groups after intervention and the control group was $.53\left(\eta^{2}\right)$ which was interpreted as high level (Cohen, 1992, p. 157; Tabachnick \& Fidell, 2013, p. 55), observed Power was 1.00, which implied that sufficient sample size and effect size affect statistical significance (Hair, Black, Babin, \& Anderson, 2010, p. 466).

4.1.5 The Parameters' Estimates of MANOVA Model of Dependent Variables

Table 6 presents the parameters' estimates of the learners' ability in vocabulary acquisition scored by vocabulary test in form and meaning recognition test among the experimental groups and the control group.

Table 6. The parameters' estimates of the learners' ability in vocabulary acquisition scored by vocabulary test in form and meaning recognition test among the experimental groups and the control group

\begin{tabular}{|c|c|c|c|c|c|c|c|}
\hline Dependent Variables & Parameter & $B$ & Std. Error & $\mathrm{t}$ & $p$ & $\eta^{2}$ & Observed Power \\
\hline \multirow{4}{*}{$\begin{array}{l}\text { Score given by } \\
\text { vocabulary test in } \\
\text { form recognition test }\end{array}$} & Intercept & 24.92 & 1.42 & $17.56^{* *}$ & 0.00 & .82 & 1.00 \\
\hline & MMGR group & 17.38 & 2.08 & $8.66^{* *}$ & 0.00 & .52 & 1.00 \\
\hline & TGR group & 10.75 & 2.08 & $5.36^{*}$ & 0.00 & .29 & 1.00 \\
\hline & Control group & $0^{\mathrm{a}}$ & & & & & \\
\hline \multirow{4}{*}{$\begin{array}{l}\text { Score given by } \\
\text { vocabulary test in } \\
\text { meaning recognition } \\
\text { test }\end{array}$} & Intercept & 22.29 & 1.43 & $15.55 * *$ & 0.00 & .78 & 1.00 \\
\hline & MMGR group & 25.96 & 2.02 & $12.85^{* *}$ & 0.00 & .71 & 1.00 \\
\hline & TGR group & 18.67 & 2.02 & $9.24 * *$ & 0.00 & .55 & 1.00 \\
\hline & Control & $0^{\mathrm{a}}$ & & & & & \\
\hline
\end{tabular}

$* * p<.01 ; \mathrm{a}=$ comparing group 
As shown in Table 6, the result of parameter estimation indicated the ability in vocabulary acquisition given by score of vocabulary test in form and meaning recognition between MMGR, TGR, and the control group after the experiment. It was found that the vocabulary acquisition as measured by form and meaning recognition scores tests of the post-experimental MMGR group was higher than TGR group, and was significantly higher than the post-test of the control group with statistically significant 0.01 .

\section{Discussion}

MMGR program developed by this present study can be used to enhance learners' competency in vocabulary acquisition since the program was systematically developed step by step. The program was developed by the integration of incidental learning and multimedia glossing with previous studies over the last decade. It can be claimed that the program is the effective tool for increasing English vocabulary recognition in foreign and second language surprisingly (Kramsch \& Andersen, 1999). The transformation of word glossing into visual and verbal input depending on the theoretical learning approach illustrating the boost of learning atmosphere in computer - based multimedia will facilitate learners to comprehend the meaning of vocabulary easily with visual and verbal program representation. (Mayer, 1997)

The adaptation of data input followed by concept mentioned above may build the learners' learning encouragement and effectiveness more than the learners read the text with traditional approach. The adaptation of data input does not change the data information and context in the reading text (Widdowson, 1984). Moreover, it can be explained that when learners focus on reading text successively by understanding the meaning of words with context-clue without looking up a word in dictionary, they will understand the text well.

The important component of the first stage in an experiment was to implement the developing method of a pilot testing to check the feasibility studies before conducting the actual experiment. The research created the application with PHP, HTML, CSS, data base in PHP Myadmin with open system where learners are able to register for engaging in reading and doing tests in activities with the access of a test result.

The application can be accessed anytime and anywhere. It is also very convenient for learners to access the program via PC, smartphone, and laptop. The program is an encouraging tool for incidental vocabulary learning which many studies claimed that it is more effective than intentional vocabulary learning (Akbulut, 2007). The finding is in agreement with what other researchers (Krashen, 1989; Nagy, Herman, \& Anderson, 1985; Nagy \& Herman, 1987) have suggested that learning media with technology such as an application will boost learners' foreign language learning. It is the means for promoting the cooperative learning, and also helps accelerate learners to have more confidence in learning. Furthermore, it will get learners have more a positive attitude toward their learning language as a foreign language dramatically which is in accordance with the research of Hao, Lee, Chen, and Sim (2019).

When comparing the learners' ability in vocabulary acquisition through programs used, MMGR program helps learners recognize vocabulary more than TGR program. From vocabulary assessment with form and meaning vocabulary recognition test, the post-test of the group treated by MMGR is higher than the group treated by TGR and the control group with statistically level at 0.01 . It is noted that learners' word recognition enhancement can be attributed MMGR program in teaching which is consistent with the study by Rezaee (2011), the investigation of the effects of various multimedia uses, such as images, movies on learning vocabulary items included in reading text. The finding indicated that learners who were exposed to reading text with pictures and video clip outperformed the learners who were exposed to reading passages with only text in learning and recalling of vocabulary which is in agreement with multimedia learning theory (Mayer, 1997). It is asserted that building the computer-based multimedia learning environments such as application use will help learners build their visual and verbal mental representations of what have been activated by a picture and a word.

In this study, it is affirmed that vocabulary learning with picture via multimedia, especially, MMGR program enable leaners to recognize vocabularies and comprehend text reading because learners decode vocabularies with dual channel (auditory and visual) for processing information as dual-coding and multimedia learning theory. The learners will build verbal and visual representations in order to make learning meaningful (Mayer \& Sims, 1994). Furthermore, it also promotes problem-solving transfer with three connections. The performance of learners' response to the tests of word retention and transfer depends on all three connections being formed visual representational connection, verbal representational connection, and referential connections. Therefore, both visual and verbal codes can be used inevitably when recalling information. In a study by Hao et al. (2019), the evaluation of mobile application designed with the framework of Cognitive Apprenticeship to facilitate learners struggling with English learning as a foreign language, it is maintained that application is not only a 
vocabulary teaching tool to create the cooperative learning but encourage learners to have a sense of learning confidence with positive attitude toward foreign language learning as well.

From the result of the Multivariance analysis of Variance (MANOVA) on the form and meaning vocabulary recognition score's test measured among three groups, it can be perceived that the ability in vocabulary recognition of learners stimulated by MMGR program is higher than any other groups because learners in this group use the concept of incidental L2 vocabulary learning which learner attention is focused to help transfer data which learners have retrieved into the memory unit of learners directly (Hulstijn, 2003). Furthermore, the findings of the study confirm what is reported by other researchers revealing that the determining vocabulary learning approach enables learners to engage in reading activity. In other word, while the learners are reading a text for understanding, they always end up with learning new words accidentally because they attempt to achieve their reading comprehension (Paribakht \& Wesche, 1999). Therefore, MMGR program is the means to help learner recognize vocabularies unintentionally during their reading. When learners retrieve the word information through glossing by both pictorial and textual representation, they are able to retrieve, recognize, recall more information, and retain words in the working memory better (AlRamadhan, 2020).

\section{Conclusion and Limitation}

This study has demonstrated that the development of Multimodal Grossing Reading Program (MMGR) can be implemented and used as the supplemental material or alternative method in the reading classroom. The program comprises 10 activities including passages and activities for vocabulary recognition. After the program had been adopted to foster learners' vocabulary retention, the post-test score was higher than a pre-test score treated by MMGR program. Comparing A post- test among being treated by the MMGR, TGR, and control group, MMGR helps learners to achieve the vocabulary retention more than TGR program. As a result, MMGR is the most effective text-visual aid program to enhance the efficiency of learners' vocabulary recognition unquestionably.

The program is also an alternative material for the instructors who used the CALL method to teach English. It can be given to learners for their practice intended vocabulary learning outside the classroom. Practicing vocabulary through extensive reading in the program could be added to extra-curricular activities in English classrooms such as a vocabulary club, a reading club in school. Moreover, the program can be used as vocabulary building strategy for instructors to use in their own classes. Therefore, the learners' expectation for their vocabulary's achievement depends on how an instructor will choose the appropriate program for a group of learners. It is wholeheartedly that if an instructor uses the program properly, a learner will get the most benefit from it perfectly.

Although the study findings have demonstrated that the program is beneficial for enhancing learners' vocabulary recognition. Some limitations should be recognized in this study. The study offers some important implications for the use of program. First, in the current study, only multiple-choice of vocabulary test in form and meaning recognition test were used to assess the learners' competency in vocabulary recognition, so the results may differ from the other assessments used, such as written vocabulary recognition test. Consequently, future studies are encouraged to cover various assessment methods. Second, learners' competency in vocabulary recognition had been assessed promptly after the learners completed using the program, so different results may be found if the reassessment was done after three months or six months. Therefore, future researches should be required to undertake reassessment for the period of time in order to perceive the effectiveness of program on vocabulary retention by exploring how much period of time do the learners retain words after programs' intervention. Other factors, including reading preferences, learning styles, prior knowledge, language proficiency may be also linked the learners' vocabulary acquisition through the multimodal reading programs, so it is suggestion that these factors mentioned earlier should be taken for the future practice's consideration.

Moreover, this potential MMGR program application may be further investigated with the studies focusing on how much the learners comprehend the reading text after studying reading via a program. In addition, the further study can also be highlighted that the adoption of the program must be applied to use for learner groups facing the learning problem in other foreign languages.

\section{Acknowledgement}

The researchers would like to thank Rajamangala University of Technology Tawan-ok for financially support the research grant and acknowledges all the associated personnel who contributed in the completion of this study. Our deep gratitude also goes to the editors and anonymous reviewers, who provide constructive feedbacks and valuable suggestions on the first version of manuscript. Any errors that remain in the paper are ours. 


\section{References}

AbuSeileek, A. F. (2011). Hypermedia annotation presentation: The effect of location and type on the EFL learners' achievement in reading comprehension and vocabulary acquisition. Computers \& Education, 57(1), 1281-1291. https://doi.org/10.1016/j.compedu.2011.01.011

AIRamadhan, M. H. (2020). L1 textual glosses and word repetition: Facilitative interventions for incidental vocabulary acquisition. International Journal of instruction, 13(4), 815-832. https://doi.org/10.29333/iji.2020.13450a

Akbulut, Y. (2007). Effects of multimedia annotations on incidental vocabulary learning and reading comprehension of advanced learners of English as a foreign language. Instructional Science, 35(6), $499-517$. https://doi.org/10.1007/s11251-007-9016-7

Anderson, R. C., \& Freebody, P. (1983). Reading comprehension and the assessment and acquisition of word knowledge. In B. Hutson (Ed.), Advances in reading/ language research: A research annual (pp. 231-256). Greenwich, CT: JAI Press.

Baddeley, A. D. (1999). Human memory. Boston: Allyn \& Bacon.

Boutorwick, T. J., Macalister, J., \& Elgort, I. (2019). Two approaches to extensive reading and their effects on L2 vocabulary development. Reading in a Foreign Language, 31(2), 150-172. Retrieved from https://files.eric.ed.gov/fulltext/EJ1232214.pdf

Bowles, M. A. (2004). L2 glossing: To CALL or not to CALL. Hispania, 87(3), 541-552. https://doi.org/10.2307/20063060

Chang, L., \& Miao, J. (2018). Comparing the effects of listening input and reading input on EFL learners' incidental vocabulary acquisition. In L. Hale, J. Zhang, L. Sun, \& Q. Fang (Eds.), Proceedings of The Fifth Northeast Asia International Symposium on Language, Literature and Translation (pp. 534-539). Marietta, Georgia: The American Scholars Press.

Coady, J. (1997). L2 vocabulary acquisition through extensive reading. In J. Coady \& T. Huckin (Eds.), Second language vocabulary acquisition (pp. 225-237). Cambridge: Cambridge University Press. https://doi.org/10.1017/CBO9781139524643.016

Cohen, J. (1992). A power primer. Psychological Bulletin, 112, 155-159. https://doi.org/10.1037/0033-2909.112.1.155

Di Iorio, C. K. (2005). Measurement in health behavior. San Francisco: Jossey-Bass A Wiley Imprint.

Duan, S. (2018). Effects of enhancement techniques on L2 incidental vocabulary learning. English Language Teaching, 11(3), 88-101. https://doi.org/10.5539/elt.v11n3p88

Ellis, R. (1995). Modified oral input and the acquisition of word meaning. Applied Linguistics, 16(4), 409-441. https://doi.org/10.1093/applin/16.4.409

Fry, E. (1977). Fry's readability graph: Clarifications, validity, and extension to level 17. Journal of Reading, 21(3), 242-252. Retrieved from https://www.jstor.org/stable/40018802

Gettys, S., Imhof, L. A., \& Kautz, J. O. (2001). Computer-assisted reading: The effect of glossing format on comprehension and vocabulary retention. Foreign Language Annals, 34(2), 91-99. https://doi.org/10.1111/j.1944-9720.2001.tb02815.x

Hair, J. F., Black, W. C., Babin, B. J., \& Anderson, R. E. (2010). Multivariate data analysis (7th ed.). Upper Saddle River, NJ: Prentice Hall.

Hao, Y., Lee, K. S., Chen, S-T., \& Sim, S. C. (2019). An evaluative study of a mobile application for middle school students struggling with English vocabulary learning. Computers in Human Behavior, 95, 208-216. https://doi.org/10.1016/j.chb.2018.10.013

Hulstijn, J. H. (2001). Intentional and incidental second language vocabulary learning: A reappraisal of elaboration, rehearsal, and automaticity. In P. Robinson (Ed.), Cognition and second language instruction (pp. 258-286). Cambridge, UK: Cambridge University Press. https://doi.org/10.1017/CBO9781139524780.011

Hulstijn, J. H. (2003). Incidental and intentional learning. In C. Doughty \& M. H. Long (Eds.), The handbook of second language acquisition (pp. 349-381). Oxford: Blackwell. https://doi.org/10.1002/9780470756492.ch12 
Hulstijn, J. H., Hollander, M., \& Greidanus, T. (1996). Incidental vocabulary learning by advanced foreign language students: The influence of marginal glosses, dictionary use, and reoccurrence of unknown words. The Modern Language Journal, 80(3), 327-339. https://doi.org/10.1111/j.1540-4781.1996.tb01614.x

Jacobs, G. M., Dufon, P., \& Hong, F. C. (1994). L1 and L2 vocabulary glosses in L2 reading Passages: Their effectiveness for increasing comprehension and vocabulary knowledge. Journal of Research in Reading, 17(1), 19-28. https://doi.org/10.1111/j.1467-9817.1994.tb00049.x

Jenkins, J. R., Stein, M. L., \& Wysocki, K. (1984). Learning vocabulary through reading. American Educational Research Journal, 21(4), 767-787. https://doi.org/10.3102/00028312021004767

Joe, A. (1998). What effects do text-based tasks promoting generation have on incidental vocabulary acquisition? Applied Linguistics, 19(3), 357-377. https://doi.org/10.1093/applin/19.3.357

Jones, L. (2004). Testing L2 vocabulary recognition and recall using pictorial and written test items. Language $\begin{array}{lllll}\text { Learning } \quad \text { and } & \text { Technology, } & \text { 122-143. } & \text { Retrieved }\end{array}$ https://128.171.57.22/bitstream/10125/43998/_03_jones.pdf

Kanoksilpatham, B., \& Khamkhien, A. (2012). English vocabulary instruction via educational TV programs in retrospect. Pasaa Paritat Journal, 27, 69-88. Retrieved from https://www.culi.chula.ac.th/Publicationsonline/files/article2/jk5qXYT4XgMon44045.pdf

Kaplan-Rakowski, R., \& Loranc-Paszylk, B. (2019). The impact of verbal and nonverbal auditory resources on explicit foreign language vocabulary learning. System, 85, 102-114. https://doi.org/10.1016/j.system.2019.102114

Kim, D., \& Gilman, D. A. (2008). Effects of text, audio, and graphic aid in multimedia instruction for vocabulary learning. Educational Technology and Society, 11(3), 114-126. Retrieved from https://citeseerx.ist.psu.edu/viewdoc/download?doi=10.1.1.596.1723\&rep=rep1\&type=pdf

Ko, M. H. (2012). Glossing and second language vocabulary learning. TESOL Quarterly, 46(1), 56-79. https://doi.org/10.1002/tesq.3

Kramsch, C., \& Andersen, R. W. (1999). Teaching text and context through multimedia. Language Learning and Technology, 2, 31-42. Retrieved from https://scholarspace.manoa.hawaii.edu/bitstream/10125/25041/02_02_article1.pdf

Krashen, S. (1989). We acquire vocabulary and spelling by reading: Additional evidence for the input hypothesis. The Modern Language Journal, 73(4), 440-464. https://doi.org/10.2307/326879

Laufer, B. (2009). Second language vocabulary acquisition from language input and from form-focused activities. Language Teaching, 42(3), 341-354. https://doi.org/10.1017/S0261444809005771

Laufer, B., \& Girsai, N. (2008). Form-focused instruction in second language vocabulary learning: A case for contrastive analysis and translation. Applied Linguistics, 29(4), 697-716. https://doi.org/10.1093/applin/amn018

Majuddin, E. (2014). The effects of differing densities of glossing on vocabulary uptake and reading comprehension. Advances in Language and Literary Studies, 5(6), 132-152. https://doi.org/10.7575/aiac.alls.v.5n.6p.132

Mayer, R. E. (1997). Multimedia learning: Are we asking the right questions? Educational Psychologist, 32(1), 1-19. https://doi.org/10.1207/s15326985ep3201_1

Mayer, R. E. (2014). The Cambridge handbook of multimedia learning. New York, NY: Cambridge University Press. https://doi.org/10.1017/CBO9781139547369

Mayer, R. E., \& Moreno, R. (2002). Aids to computer-based multimedia learning. Learning and Instruction, 12(1), 107-119. https://doi.org/10.1016/S0959-4752(01)00018-4

Mayer, R. E., \& Sims, V. K. (1994). For whom is a picture worth a thousand words? Extensions of a dual-coding theory of multimedia learning. Journal of Educational Psychology, 86, 289-401. Retrieved from https://doi.org/10.1037/0022-0663.86.3.389

McGriff, S. J. (2000). Instructional System Design (ISD): Using the ADDIE model. Instructional Design Models, $226(14), 1-2$.

McMillan, J. H., \& Schumacher, S. (2010). Research in education: Evidence-based inquiry. Boston: Pearson Higher Ed. 
Nagy, W. E., \& Herman, P. A. (1987). Breadth and depth of vocabulary knowledge: Implications for acquisition and instruction. In M. G. McKeown \& M. E. Curtis (Eds.), The nature of vocabulary acquisition (pp. 19-35). Hillsdale, NJ: Erlbaum.

Nagy, W. E., Herman, P. A., \& Anderson, R. C. (1985). Learning words from context. Reading Research Quarterly, 20(2), 233-253. https://doi.org/10.2307/747758

Nagy, W. E., Anderson, R. C., \& Herman, P. A. (1987). Learning word meanings from context during normal reading. American Educational Research Journal, 24(2), 237-270. https://doi.org/10.3102/00028312024002237

Nation, I. S. P. (1990). Teaching and learning vocabulary. New York: Newbury House/ Harper \& Row.

Nation, I. S. P. (2001). Language vocabulary in another language. Cambridge: Cambridge University Press. https://doi.org/10.1017/CBO9781139524759

Nation, I. S. P. (2005). Teaching vocabulary. Asian EFL Journal, 7(3), 47-54.

Oxford, R. L., \& Scarcella, R. C. (1994). Second language vocabulary learning among adults: State of the art in vocabulary instruction. System, 22(2), 231-243. https://doi.org/10.1016/0346-251X(94)90059-0

Paivio, A. (1986). Mental representations: A dual coding approach. New York: Oxford University Press.

Paribakht, T. S., \& Wesche, M. (1999). Reading and "incidental” L2 vocabulary acquisition: An introspective study of lexical inferencing. Studies in Second Language Acquisition, 21(2), 195-224. https://doi.org/10.1017/S027226319900203X

Paribakht, T., \& Wesche, M. (1997). Vocabulary enhancement activities and reading for meaning in second language vocabulary acquisition. In J. Coady \& T. Huckin (Eds.), Second language vocabulary acquisition: A rationale for pedagogy (pp. 174-200). Cambridge: Cambridge University Press. https://doi.org/10.1017/CBO9781139524643.013

Pellicer-Sanchez, A. (2014). Incidental vocabulary acquisition from an authentic novel. Reading in a Foreign Language, 22(1), 31-55. Retrieved from https://scholarspace.manoa.hawaii.edu/bitstream/10125/66652/1/22_1_10125_66652_pellicersanchez.pdf

Rassaei, E. (2018). Computer-mediated textual and audio glosses, perceptual style and L2 vocabulary learning. Language Teaching Research, 22(6), 657-675. https://doi.org/10.1177/1362168817690183

Read, J. (2004). Plumbing the depths: How should the construct of vocabulary knowledge be defined? In P. Bogaard \& B. Laufer (Eds.), Vocabulary in a second language: Selection, acquisition and testing (pp. 209-227). Amsterdam: John Benjamins. https://doi.org/10.1075/1llt.10.15rea

Rezaee, A. A. (2011). Investigating the effect of using multiple sensory modes of glossing vocabulary items in a reading text with multimedia annotations. English Language Teaching, 4(2), 25-34. https://doi.org/10.5539/elt.v4n2p25

Richards, J. C., \& Schmidt, R. (2002). Longman dictionary of language teaching and applied linguistics. London: Pearson Education.

Rott, S. (1999). The effect of exposure frequency on intermediate language learners' incidental vocabulary acquisition and retention through reading. Studies in Second Language Acquisition, 21(4), 589-619. https://doi.org/10.1017/S0272263199004039

Sakar, A., \& Ercetin, G. (2005). Effectiveness of hypermedia annotations for foreign language reading: Hypermedia annotations for foreign language reading. Journal of Computer Assisted Learning, 21(1), 28-38. https://doi.org/10.1111/j.1365-2729.2005.00108.x

Schmitt, N. (2008). Instructed second language vocabulary learning. Language Teaching Research, 12(3), 329-363. https://doi.org/10.1177/1362168808089921

Schmitt, N., Jiang, X., \& Grabe, W. (2011). The percentage of words known in a text and reading comprehension. The Modern Language Journal, 95(1), 26-43. https://doi.org/10.1111/j.1540-4781.2011.01146.x

Severin, R. (2019). L1 audio and textual glosses for incidental vocabulary learning through reading (Master's thesis, Iowa State University, United State of American). Retrieved from https://lib.dr.iastate.edu/etd/17559

Stahl, S. A. (1999). Vocabulary development. Newton Upper Falls, MA: Brookline Books. 
Sun, C-H. (2017). The value of picture-book reading-based collaborative output activities for vocabulary retention. Language Teaching Research, 21(1), 96-117. https://doi.org/10.1177/1362168816655364

Sweller, J., Ayres. P., \& Kalyuga, S. (2011). Cognitive load theory. New York: Springer. https://doi.org/10.1007/978-1-4419-8126-4

Tabachnick, B. G., \& Fidell, L. S. (2013). Using multivariate statistics (6th ed.). Boston, MA: Pearson.

Tang, Z. (2020). A review on studies into incidental vocabulary acquisition through different input. English Language Teaching, 13(6), 89-95. https://doi.org/10.5539/elt.v13n6p89

Vazquez-Calvo, B., Zhang, L. T., Pascual, M., \& Cassany, D. (2019). Fan translation of games, anime, and fanfiction. Language Learning \& Technology, 23(1), 49-71.

Vidal, K. (2003). Academic listening: A source of vocabulary acquisition? Applied Linguistics, 24(1), 56-89. https://doi.org/10.1093/applin/24.1.56

Vidal, K. (2011). A comparison of the effects of reading and listening on incidental vocabulary acquisition. Language Learning, 61(1), 219-258. https://doi.org/10.1111/j.1467-9922.2010.00593.x

Webb, S. (2005). Receptive and productive vocabulary learning: The effects of reading and writing on word

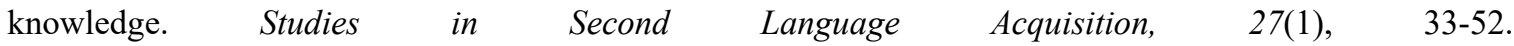
https://doi.org/10.1017/S0272263105050023

Widdowson, H. G. (1984). Teaching language as communication. Oxford: Oxford University Press.

Wittrock, M. C. (1989). Generative processes of comprehension. Education Psychologist, 24(4), 345-376. https://doi.org/10.1207/s15326985ep2404_2

Yanguas, I. (2009). Multimedia glosses and their effect on L2 text comprehension and vocabulary learning. Language Learning \& Technology, 13(2), 48-67. Retrieved from https://scholarspace.manoa.hawaii.edu/bitstream/10125/44180/13_02_yanguas.pdf

Yeh, Y., \& Wang, C. (2003). Effects of multimedia vocabulary annotations and learning styles on vocabulary learning. CALICO Journal, 21(1), 131-144. https://doi.org/10.1558/cj.v21i1.131-144

Yoshii, M. (2006). L1 and L2 glosses: Their effects on incidental vocabulary learning. Language Learning and Technology, 10(3), 58-101. Retrieved from https://scholarspace.manoa.hawaii.edu/bitstream/10125/44076/10_03_yoshii.pdf

Zarei A. A., \& Rashvand, Z. (2011). The effect on interlingual and intralingual verbatim and nonverbatim subtitles on L2 vocabulary comprehension and production. Journal of Language Teaching and Research, 2(3), 618-625. https://doi.org/10.4304/jltr.2.3.618-625 


\section{Appendix}

Multimodal Glossing Reading Program (MMGR)
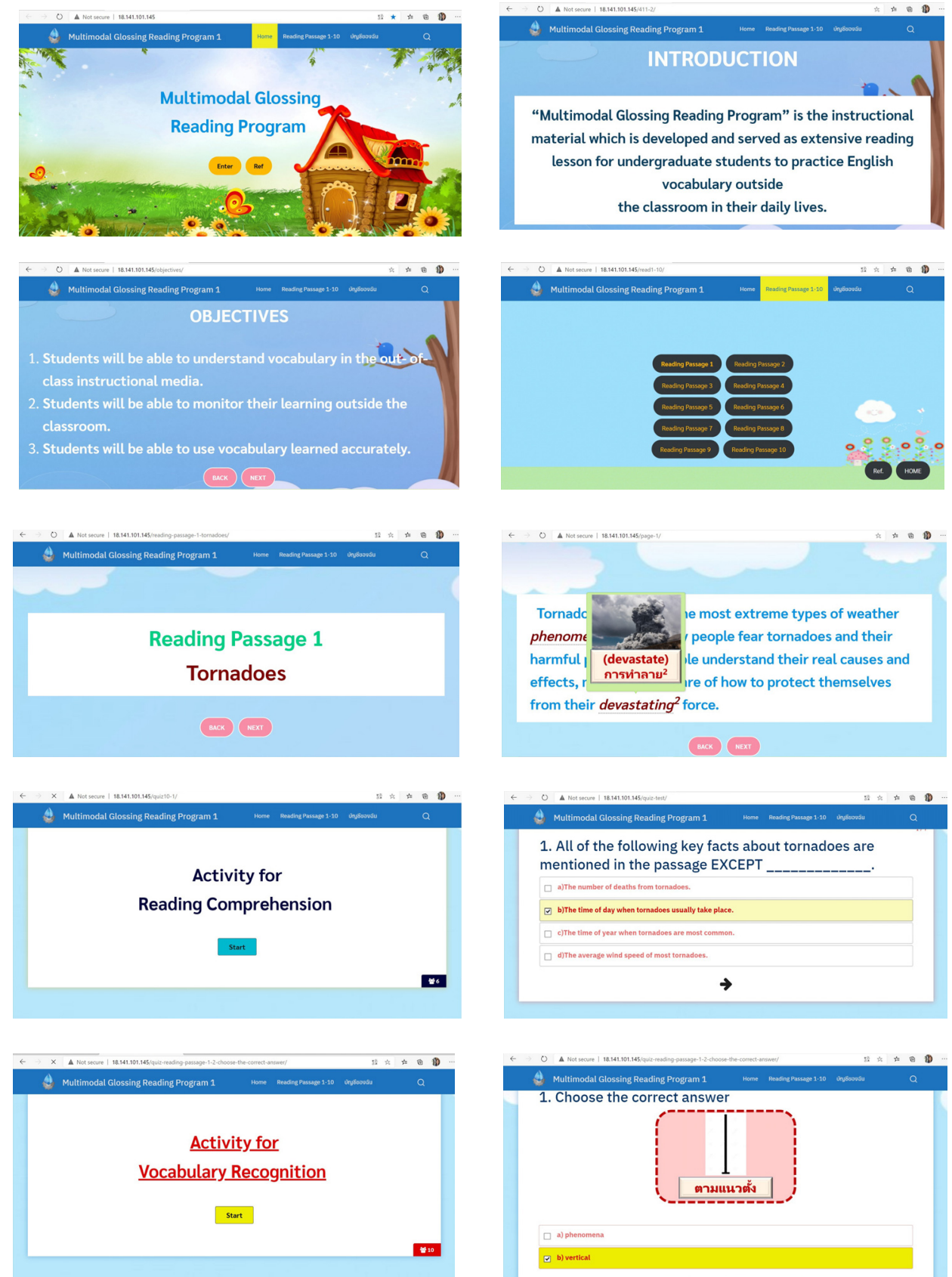

Figure 1. The detail of MMGR program

\section{Copyrights}

Copyright for this article is retained by the author(s), with first publication rights granted to the journal.

This is an open-access article distributed under the terms and conditions of the Creative Commons Attribution license (http://creativecommons.org/licenses/by/4.0/). 